Gill, C., Mullen, T. and Vivian, N. (2020) The managerial ombudsman. Modern Law Review, 83(4), pp. 797-830.

There may be differences between this version and the published version. You are advised to consult the publisher's version if you wish to cite from it.

This is the peer reviewed version of the following article:

Gill, C., Mullen, T. and Vivian, N. (2020) The managerial ombudsman. Modern Law Review, 83(4), pp. 797-830. (doi: 10.1111/1468$\underline{2230.12523}$ )

This article may be used for non-commercial purposes in accordance with Wiley Terms and Conditions for Self-Archiving.

http://eprints.gla.ac.uk/206016/

Deposited on: 17 December 2017

Enlighten - Research publications by members of the University of Glasgow http://eprints.gla.ac.uk/ 


\title{
The managerial ombudsman*
}

\begin{abstract}
This article identifies a major development in the role and practice of the ombudsman. It argues that the New Public Management practices that have transformed public administration in the last 30 years have led to a more managerial approach to the ombudsman's work. The article's argument is developed through analysis of an empirical case study of the Scottish Public Services Ombudsman, which illustrates how the aims and techniques of managerialism have been deployed in the ombudsman context. The article evaluates the significance of these developments for the ombudsman institution and for the wider justice system. It examines the risks and opportunities inherent in this turn to managerialism and whether it represents a departure from the ombudsman's mission or a necessary adaptation to a changed world of public administration. In identifying the rise of the 'managerial ombudsman', the article provides a new framework for conceptualising developments in the modern ombudsman institution.
\end{abstract}

\section{INTRODUCTION}

Ombudsman offices are independent bodies that investigate complaints from citizens about government administration and provide additional remedies to those traditionally available in courts. Having been developed in Scandinavia in the $19^{\text {th }}$ century, the ombudsman institution began to spread around with the world in the mid- $20^{\text {th }}$ century and is now a feature of citizens' redress in most jurisdictions. The first UK ombudsman was created in 1967 and was intended primarily as an aid to parliamentarians in their traditional role of redressing their constituents' grievances. This function was reflected in the ombudsman's modus operandi, which focused on formal complaint investigations, reporting outcomes to Parliament, and making non-binding recommendations designed to have political rather than legal effects. This approach, described as the "officer of Parliament" model, ${ }^{1}$ began to come under pressure, as volumes of complaints increased and as new ombudsman offices were set up, in areas like health and local government, without a distinct parliamentary link. Increasingly, having been first thought of as an elite remedy, a 'cutting edge' for the prime benefit of MPs, ${ }^{2}$ UK ombudsman offices adopted a role more akin to a small claims court, providing mass redress of public service complaints.

\footnotetext{
${ }^{1}$ C. Harlow, 'Ombudsmen: hunting lions or swatting flies' in M. Hertogh and R. Kirkham, Handbook of ombudsman research (Cheltenham: Edward Elgar, 2018). The references to small claims court and inspector general approaches below are also discussed by Harlow.

2 G. Drewry and C. Harlow, 'A 'cutting edge'? The Parliamentary Commissioner and MPs' (1990) 53 The Modern Law Review 6.
} 
Despite the focus of ombudsman statutes remaining on formal investigations and reports, ombudsman offices responded to their growing workloads by using less formal methods and seeking increasingly to resolve complaints without formal reporting to Parliament. At the same time - despite not having a clear statutory remit to do so - UK ombudsman offices have moved towards the so-called "inspector general” model, through the investigation of groups of 'big cases' and the issuing of good practice guidance seeking to achieve a broader systemic impact on public administration. The result of these developments have been something of a hotchpotch, with a lack of clarity over what function the UK's ombudsman offices are, and should be, fulfilling, and the means they should employ for doing so.

It is in this context that this article argues that, in the last 30 years, a distinctive model of ombudsman practice has developed. Recalling Resnick's identification of the 'managerial judge', ${ }^{3}$ the article argues that an important ombudsman model in the UK is now that of the 'managerial ombudsman'. ${ }^{4}$ Indeed, the article contends that understanding the current approach to the ombudsman institution in the UK as a response to - and a part of - the post-1990s managerialisation of public services provides a fresh and insightful means of conceptualising the modern ombudsman institution. An outline of the managerial ombudsman may be briefly stated. It involves, first, the adoption of managerialist language to describe the role of the ombudsman and its relationship to public administration. Second, it recasts the aims of the ombudsman as being to provide satisfaction to 'consumers' of public services and emphasises its role in supporting public managers to improve services. Third, it internalises techniques of modern managerialism in its own organisation, for example, using Key Performance Indicators, targets, customer satisfaction surveys, and other approaches emphasising efficiency in providing an ombudsman 'service'. Fourth, it is influenced by complaint handling in the private sector, including an emphasis on 'informal resolution', rather than the traditional approach of conducting public accountability investigations. ${ }^{5}$ Lastly, the major emphasis of the managerial ombudsman rests on the idea of learning from complaints, with this agenda seen as a way of carving out a legitimate 'domain ${ }^{6}$ for ombudsman offices within a reformed public administration.

The article advances its argument in two ways. Part II provides theoretical context and aims to demonstrate the influence of consumerist and managerial agendas in the development of the UK's complaint handling and ombudsman systems. Part III then describes a small-scale empirical case study, which illustrates how the managerial ombudsman model is currently being developed in the UK. The case study considers developments in the role of the Scottish Public Services Ombudsman. Briefly, this

\footnotetext{
* The authors are grateful to [...]

${ }^{3}$ J. Resnick, 'Managerial Judges’ (1982) 96 Harvard Law Review 374.

${ }^{4}$ This article is concerned with the ombudsman institution in the UK. At the same time, the argument is likely to be of interest in other jurisdictions where there have been large-scale managerial reforms of public administration and where managerialism becomes a more important feature in the design and operation of justice systems.

${ }^{5}$ J. Gulland, 'Taking complaints seriously: the role of informality in complaints about public services' (2011) 10 Social Policy and Society 4.

${ }^{6}$ S. Gilad, 'Exchange without capture: The UK financial ombudsman service's struggle for accepted domain' (2008) 86 Public Administration 4.
} 
involves an enhanced role in setting and monitoring standards for complaint handling, simplifying complaint procedures, and supporting the development of good practice in complaint handling. The article argues that this represents a significant extension to the managerial ombudsman model, particularly in relation to (a) the way that the ombudsman's mission has shifted further towards a managerial concern with organisational learning, and (b) in the novel methodologies (such as performance indicators, benchmarking, and consultancy) which have been developed to support the ombudsman's expanded mission. This case study, it will be argued, is significant in the UK given the development of similar approaches in the devolved jurisdictions of Wales and Northern Ireland. It is also significant internationally, because it allows for the identification of a distinct model of ombudsman practice and novel methodologies. Drawing on documentary analysis and qualitative interviews, the case study provides insights into the development, risks, and opportunities of the managerial ombudsman model.

The article is not restricted to conceptualising the development of the 'managerial ombudsman', but also provides a critical evaluation, which is both philosophical and practical. The philosophical discussion draws on critiques of consumerism and private sector practice in public services and raises questions about the appropriateness of the ombudsman's co-option of managerial values and techniques. Is the managerial ombudsman a reductive and debased version of the ombudsman's original mission? Or does it represent a pragmatic and powerful adaptation to a changed world of public administration? The practical critique relates to the pitfalls of adopting managerialist language, goals, and methodologies. Can ombudsman offices 'satisfy' consumers of public services in the way their private sector counterparts might? And can ombudsman offices really deliver on the potential for complaints to lead to better public services? The particular focus of the article, here, is on the opportunities and challenges of the growing emphasis on learning from complaints. The article argues that the opportunity of this learning agenda is to provide an escape from the traditional tension haunting the ombudsman's role, between retrospective accountability and prospective regulation. ${ }^{7}$ The main risks involve the danger of the ombudsman becoming too proactively drawn into public service improvement and the well-known challenges that stand in the way of learning in public services. ${ }^{8}$

The article ends by reflecting on the significance of the case study and the managerial ombudsman approach. Globally, the major story of the ombudsman's development has been a growing emphasis on human rights, good governance, and the rule of law, ${ }^{9}$ which stands quite apart from the managerial focus the article identifies in the UK. Here, the article explores whether the models are simply in opposition or whether there is potential for them to be reconciled. Finally, the article ends by

\footnotetext{
${ }^{7}$ G. Smith, 'Citizen oversight of independent police services: Bifurcated accountability, regulation creep, and lesson learning' (2009) 3 Regulation \& governance 4.

${ }^{8}$ C. Gill, 'What can government learn from the ombudsman?' in M. Hertogh and R. Kirkham (eds), The handbook of ombudsman research, (Cheltenham: Edward Elgar, 2018 forthcoming).

${ }^{9}$ L. Reif, The ombudsman, good governance, and the international human rights system (Leiden: Martinus Nijhoff Publishers, 2004)
} 
contextualising the managerial ombudsman within recent reforms of the justice system. Here, the article argues that the managerial ombudsman model can be situated more precisely as part of a broader enterprise of managerialist justice system reform. The wider significance of the model analysed in this article, then, is to provide a case study of managerial reform that contributes to understanding the ways in which justice systems are changing in the modern managerial state.

The article is structured in three parts. Part II provides the theoretical context. Part III presents the case study methodology and findings. Part IV discusses the findings and concludes by analysing the significance of the managerial ombudsman model.

\section{THEORETICAL CONTEXT}

This part of the article provides context for the case study in Part III. Section A argues that modern developments in complaint handling and the ombudsman's role have been driven by a New Public Management (NPM) agenda. Section B makes the argument that the contemporary focus of the ombudsman is on 'lesson-learning' and that this focus comes with opportunities and risks. Section C ends by reviewing performance management techniques, such as performance measurement and benchmarking that are being applied for the first time in the ombudsman context.

\section{A. Complaint handling in UK public services and the managerial paradigm}

\section{Developments in complaint handling in the United Kingdom}

For analytical clarity, and despite some oversimplification, it is helpful to consider modern developments in public service complaint handling as occurring in three broad phases (see table 1 below). Phase 1 involved the development of external procedures and accompanied the significant growth of the welfare state in the post-war period. This phase conforms to a 'legal model' ${ }^{10}$ of complaint management, supplemented by the ombudsman's 'administrative model', ${ }^{11}$ associated with values such as due process and fair treatment. Phase 2 involved the development of internal procedures, this time accompanying the New Public Management (NPM) reforms of the 1980s and 1990s. This phase conformed to a 'managerial model', associated with values such as customer service and government responsiveness. ${ }^{12}$ Finally, the third phase has involved attempts to reform developments of phase 1 and phase 2, with an emphasis on how the whole complaints 'system' operates. This phase conforms to a systemic-managerial model, where managerialism remains at the heart of complaint handling, but more

\footnotetext{
${ }^{10} \mathrm{~J}$. Allsop and K. Jones, 'Withering the citizen, managing the consumer: complaints in healthcare settings' (2008) 7 Social Policy and Society 2.

${ }^{11}$ D. Clark, 'Managerialism, administrative justice and public service reform in Britain' (1999) 65 International Review of Administrative Sciences 4.

${ }^{12}$ Ibid.
} 
emphasis is placed on the system's coherence, cost, and effectiveness. The paragraphs below analyse each phase.

\begin{tabular}{|l|l|l|l|l|}
\hline Phase & Time period & Key development & Underlying values & Model \\
\hline 1 & 1950 s -1970s & $\begin{array}{l}\text { Growth in external mechanisms } \\
\text { with either a legal or } \\
\text { administrative focus e.g. } \\
\text { tribunals and ombudsman }\end{array}$ & $\begin{array}{l}\text { Rule of law, due } \\
\text { process, citizen } \\
\text { rights, independence, } \\
\text { public adjudication, } \\
\text { fair treatment, good } \\
\text { administration }\end{array}$ & $\begin{array}{l}\text { Legal - } \\
\text { administrative - } \\
\text { external }\end{array}$ \\
\hline 2 & $1980 s-$ & $\begin{array}{l}\text { Internal, managerially-focused } \\
\text { complaint mechanisms e.g. } \\
\text { complaint procedures, internal } \\
\text { review processes }\end{array}$ & $\begin{array}{l}\text { Flexibility, customer } \\
\text { service, government } \\
\text { responsiveness, } \\
\text { service improvement }\end{array}$ & $\begin{array}{l}\text { Managerial - } \\
\text { internal }\end{array}$ \\
\hline 3 & $2000 s-$ & $\begin{array}{l}\text { Systemic attempts to reform } \\
\text { phase 1 and 2 mechanisms e.g. } \\
\text { Tribunals Courts and } \\
\text { Enforcement Act 2007, Public } \\
\text { Services Reform Scotland Act } \\
2010 s\end{array}$ & $\begin{array}{l}\text { Efficiency, } \\
\text { simplification, } \\
\text { coherence, value for } \\
\text { money }\end{array}$ & $\begin{array}{l}\text { mystemic - } \\
\text { managerial - } \\
\text { holistic }\end{array}$ \\
\hline
\end{tabular}

Table 1: developments in public service complaint handling

In phase 1, a growing state led to a concern with limiting bureaucratic power and ensuring the availability of remedies. The emphasis was on external redress, with the provision of appeal rights and independent tribunals drawing on legal principles and formal procedures. ${ }^{13}$ Franks confirmed in 1957 that tribunals formed part of the adjudicative arm of the state and should conform to principles of fairness, openness, and impartiality. A 'new legalism' could be seen in arrangements for public sector redress in the UK in the 1960s and 1970s, emphasising principles of legality, natural justice, and rationality. ${ }^{14}$ Such approaches to redress were in keeping with Weberian notions of bureaucracy, with their emphasis on impartiality, rationality, and governance by rules. The introduction of the

${ }^{13}$ Ibid. 
Parliamentary Commissioner for Administration in 1967, while seeking to ensure that redress was available for poor administration that was nevertheless lawful, continued to emphasise a need for formal, external mechanisms of redress. This was supplemented in the National Health Service ReOrganisation Act 1993 with the creation of the Health Services Commissioner as an ombudsman for health service complaints and in the Local Government Act 1974 with the creation of the Commission for Local Administration as an ombudsman for local government. Hence the focus in the post-war period was on the expansion of external mechanisms for redress, emphasising independence in the adjudication of complaints according to law and good administration.

Phase 2 saw a shift in public administration and the complaints machinery. Clark refers to this second wave being driven by more ideological and managerial agendas. ${ }^{15}$ Adler meanwhile refers to public sector reforms leading to a raft of new models of administrative justice entering bureaucratic practice, including managerial, consumerist, and market models. ${ }^{16}$ These reforms can be seen as part of a trend across Europe to enhance mechanisms for consumer voice. ${ }^{17}$ Complaints became re-imagined as means by which the aims of NPM - including using market mechanisms and a consumer orientation to public services - could be furthered. Indeed, complaint mechanisms became tools for remedying inefficient administration and creating more demanding consumers of public services. ${ }^{18}$ Just as the NPM reforms imported private sector practice to management, so complaint handling mechanisms emphasised an internal managerialist focus rather than one which provided independent public adjudication. Adler's ${ }^{19}$ analysis is that consumerist approaches to decision-making were associated with the 'voice' mode of redress and compensation through consumer charters. ${ }^{20}$

Indeed, the landmark development was the Citizen's Charter, which had two aims: to encourage public services to publish standards for delivery and provide mechanisms to challenge failures to meet standards. ${ }^{21}$ Drawing on Halliday and Scott's ${ }^{22}$ cultural analysis of administrative justice, these developments can be seen as resulting in a shift in both bureaucratic practice and redress from an ideal type emphasising hierarchism (valuing expertise and the implementation of 'higher orders') to an ideal type conforming more closely to individualism (valuing bargaining and consumer

\footnotetext{
15 Ibid.

${ }^{16}$ M. Adler, 'Understanding and analysing administrative justice', in M. Adler (ed), Administrative Justice in Context (Oxford: Hart, 2010).

${ }^{17}$ S. Jilke and S. Van de Walle, 'Two track public services? Citizens' voice behaviour towards liberalized services in the EU15’ (2013) 15 Public Management Review 4.

${ }^{18} \mathrm{P}$. Birkinshaw, 'Grievances, remedies and the state-revisited and re-appraised' in M. Adler (ed) Administrative justice in context (Oxford: Hart Publishing, 2010).

${ }^{19} \mathrm{~N} 16$ above.

20 'Voice' is a concept developed by Hirschman to describe one of three typical behaviours resulting from dissatisfaction with a service and refers to expressing dissatisfaction (such as through complaining). A Hirschman, Exit, Voice, and Loyalty: Responses to Decline in Firms, Organisations, and States (Harvard: Harvard University Press, 1972).

${ }^{21}$ The Citizen's Charter: Raising The Standard, Cm 1599 (1991).

22 S. Halliday and C. Scott, 'A cultural analysis of administrative justice' in M. Adler (ed) Administrative justice in context (Oxford: Hart Publishing, 2010).
} 
responsiveness). Following the introduction of the Charter, the Cabinet Office set up a Complaint Taskforce, which drew heavily on private sector practice to draw up principles for complaint handling. ${ }^{23}$ Since the Charter, internal complaints procedures have become universal in the public sector. ${ }^{24}$

Phase 3 combined managerial concerns with a more holistic approach. Attention came to rest on two issues: the design and effectiveness of complaint systems. This systemic approach can be seen in attempts at improving cooperation between local and national ombudsman offices ${ }^{25}$ and the creation of the Cross Government Complaints Forum. ${ }^{26}$ The UK Parliament's Public Administration Select Committee ${ }^{27}$ also began taking a greater interest in complaint handling. ${ }^{28} \mathrm{~A}$ major contribution to the systemic approach came with the 2004 White Paper, Transforming Public Services: Complaints, Redress, and Tribunals, which called for a more rational and cost-effective system. ${ }^{29}$ The White Paper's vision was partly implemented in the Tribunals, Courts, and Enforcement Act 2007, but only in relation to the tribunal system. Indeed, the adoption of a more holistic and systemic approach is best demonstrated in the rationalisation of tribunals into a unified court and tribunal service. In comparison, despite continuing concerns about internal complaint handling and the ombudsman, reform in these areas has been limited. ${ }^{30} \mathrm{~A}$ draft ombudsman reform Bill has been published but the timetable for introducing a Bill to Parliament is unclear. ${ }^{31}$

At a UK level, therefore, concern with systemic issues increased, but reform was imperfectly realised outwith the tribunal sector. This contrasts with devolved nations, where ombudsman and complaint handling systems have been subject to substantial systemic-managerial reform. A key development was the creation of 'one-stop-shop' ombudsman offices, with integrated jurisdictions covering most public services. ${ }^{32}$ Devolved reform also tackled internal complaint handling. In Wales, a single portal for complaining about public services was created. The Public Service Ombudsman for Wales was also given a non-statutory remit to standardise complaint processes. Meanwhile, in Scotland, following reforms prompted by the Crerar Review, ${ }^{33}$ the Scottish Public Service Ombudsman was given

\footnotetext{
${ }^{23}$ M. Blackmore, 'Complaints Within Constraints: A Critical Review and Analysis of the Citizen's Charter Complaints Task Force’ (1997) 12 Public Policy and Administration 3.

${ }^{24} \mathrm{~N} 18$ above.

${ }^{25}$ Draft Public Services Ombudsman Bill CBP 7864 (2016)

${ }^{26} \mathrm{~J}$. Gulland, 'Independence in complaints procedures: lessons from community care', (2009) 31 Journal of Social Welfare \& Family Law 1.

${ }^{27}$ Now the Public Administration and Constitutional Affairs Committee.

${ }^{28}$ More complaints please! HC229 (2014)

${ }^{29}$ Transforming Public Services: Complaints, Redress, and Tribunals CM6243 (2004).

${ }^{30}$ For example, P. Dunleavy, S. Bastow, J. Tinkler, S. Goldchluk, E. Towers 'Joining up citizen redress in UK central government’ in M. Adler (ed.), Administrative justice in context, (Oxford: Hart, 2010) and R. Gordon, Better to serve the public: Proposals to restructure, reform, renew and reinvigorate public services ombudsmen (Cabinet office, 2014).

${ }^{31} \mathrm{~N} 25$ above.

${ }^{32} \mathrm{C}$. Gill, "The evolving role of the ombudsman: a conceptual and constitutional analysis of the" Scottish solution" to administrative justice' (2014) Public law.

${ }^{33} \mathrm{~L}$. Crerar. Independent review of regulation, audit, inspection, and complaint handling. (Edinburgh: Scottish Government, 2007).
} 
a new statutory function to oversee standardised complaints procedures across Scottish public services. ${ }^{34}$ These reforms are the subject of the case study below.

\section{Critiques of the managerialist complaint handling model}

Critiques of these developments have focused on the values underlying managerial complaint handling. As Allsop and Jones argue, ${ }^{35}$ complaint systems are not value free and there have been concerns about managerial values encroaching into justice provision. Despite the current hold of managerialism, alternatives are possible. For instance, complaints are described by Chen et al. as fundamental aspects of democracy and means of creating a more participatory state. ${ }^{36}$ Brewer meanwhile conceptualises them as channels through which citizens can hold government to account and build confidence in institutions. ${ }^{37}$ O'Brien - referring to public service ombudsman offices - sees their role being to contribute to public governance through processes of deliberative decision-making. ${ }^{38}$ Such democratic visions are, however, under-developed in practice. Rather than being underpinned by citizenship and democratic participation, developments in the UK show a movement away from those values. Indeed, referring to healthcare complaints, Allsop and Jones argue that such models have been displaced by one 'based on corporate sector practice that views complaint handling as a way of retaining customers and organisational learning' ${ }^{39}$ This approach is a 'consumer-populist variant' of NPM, combining managerialism and consumerism. ${ }^{40}$

Brewer identifies the problems with this approach as its emphasis on customer satisfaction at the expense of citizens' rights, its weakening of public service values, and its move away from the rule of law. ${ }^{41}$ The major concern with consumerism is its reduction of the multi-dimensional concept of citizenship to one based on self-interest and transactional understandings of public provision as 'service delivery'. ${ }^{42}$ These concerns are reflected in wider critiques of consumerism in public services. In particular, reconceptualising citizens as consumers may marginalise the excluded, allowing the powerful in society to distort services in their favour, ${ }^{43}$ creating a 'two track public service'. ${ }^{44}$ An

\footnotetext{
${ }^{34} \mathrm{~N} 35$ above.

${ }^{35} \mathrm{~N} 10$ above.

${ }^{36}$ D. Chen, T. Huang, and N. Hsaio, 'The management of citizen participation in Taiwan: a case study of Taipei city government's citizen complaints system’ (2003) 26 International Journal of Public Administration, 5.

37 B. Brewer, 'Citizen or customer? Complaints handling in the public sector' (2007) 73 International Review of Administrative Sciences 4.

${ }^{38}$ N. O'Brien, 'What future for the ombudsman?’ (2015) 86 The Political Quarterly 1.

${ }^{39} \mathrm{~N} 10$ above.

${ }^{40} \mathrm{~N} 11$ above.

${ }^{41} \mathrm{~N} 372$ above.

42 C. Needham, 'Customer care and the public service ethos. Public Administration' (2006) 84 Public Administration 4.

${ }^{43}$ T. Jung, 'Citizens, co-producers, customers, clients, captives? A critical review of consumerism and public services’ (2010) 12 Public Management Review 3.

${ }^{44} \mathrm{~N} 17$ above.
} 
example of the potential distortive effects of complaint systems has recently been provided by Hubeau, who discusses the way in which ombudsman systems have the potential to create "Matthew effects" that take resources away from the most needy. ${ }^{45}$ While the more powerful in society have always been in a better position to capture public services, the expansion of consumerist approaches emphasising consumer empowerment and the growth of complaint procedures have the potential to exacerbate this. Such approaches also exclude others interested in public service delivery: future service users; excluded users and non-users; and citizens at large. ${ }^{46}$

Another critique focuses on informality, which Gulland argues recasts complaints as consumer issues to be 'sorted out'. ${ }^{47}$ Goldsmith sees informality as a response to managerial demands for efficiency, ${ }^{48}$ while Nader argues that informality is a means of 'cooling out' complainants. ${ }^{49}$ Gilad refers to this as 'expectations management' where the emphasis is on re-adjusting the (perceived to be) excessive demands of citizens. ${ }^{50}$ The major critique of informality is that it lacks transparency and reduces complaints to atomised, transactional matters: serious issues are not brought to public attention, and do not lead to the democratic discussions advocated by O’Brien. ${ }^{51}$ A further concern with informality is the suspicion that it is driven by cost reduction. Gulland makes this point in discussing the reframing of informality as 'proportionality', with proportionality becoming code for ensuring that complaints are dealt with at the lowest cost. ${ }^{52}$

Clark has provided a more balanced account and argues that rather than being in opposition to the traditional external mechanisms of administrative law, consumerist approaches may in fact offer an internal complement to external remedies. ${ }^{53}$ Consumerist ideas of individual consumer rights can be seen as fitting with a legalistic model of individual redress and potentially enhancing the rights of citizens in relation to the state, rather than weakening them through an inferior conception of citizenship. Similarly, dispute resolution scholars have identified benefits to be derived from informal approaches to complaints, which can provide quicker, less stressful, more consensual results that can benefit both

\footnotetext{
${ }^{45}$ B. Hubeau, 'The Profile of Complainants: How to Overcome the 'Matthew Effect'?' in M. Hertogh and R. Kirkham, Handbook of ombudsman research (Cheltenham: Edward Elgar, 2018). A 'Matthew effect' is a concept that describes situations where a facility, apparently designed for everyone, is in fact more likely to widen the gap between those with resources and those without. The term derives from the Parable of the Talents recounted in the Gospel according to St Matthew: 'For to everyone who has will more be given, and he will have an abundance. But from the one who has not, even what he has will be taken away'(Chapter 25, Verse 29).

${ }^{46}$ W. Staples, and J. Dalrymple, 'Customer service in local government: an Australian experience' (2006) Proceedings of the 20th ANZAM (Australian New Zealand Academy of Management) Conference on "Management: Pragmatism, Philosophy, Priorities", 6-9 December 2006, Central Queensland University. ${ }^{47} \mathrm{~N} 5$ above.

${ }^{48}$ A. Goldsmith 'Informal resolution of police complaints in Australia: Building better understanding or mere bureaucratic convenience’ (2000) 17 Law in Context: A Socio-Legal Journal 1.

${ }^{49}$ L. Nader. The life of the law: anthropological projects. (California: University of California Press, 2002).

${ }^{50}$ S. Gilad, 'Accountability or expectations management? The role of the ombudsman in financial regulation' (2008) 30 Law \& Policy 2.

${ }^{51} \mathrm{~N} 38$ above.

${ }^{52} \mathrm{~N} 5$ above.

${ }^{53} \mathrm{~N} 11$ above.
} 
complainants and public bodies. ${ }^{54} \mathrm{~A}$ question remains, therefore, about whether shifts towards more managerial, informal, and consumerist models of redress weaken or enhance the protections available to citizens. Indeed, in this regard, Adler has argued that internal measures - rather than external mechanisms - may offer the best means of securing justice in administration. ${ }^{55}$

\section{The ombudsman's role}

This article argues that managerialist approaches have influenced the practice of UK ombudsman offices, and that this presents challenges and opportunities. The ombudsman can be seen as a nested institution, ${ }^{56}$ whose institutional context means that broader reforms of public administration particularly the growth of NPM discussed above - have influenced the way in which the ombudsman works and defines its role. Evidence of the significance of managerialism for ombudsman offices can be seen in the role they have played in the development of internal complaint systems. As early as 1993, the Local Government Ombudsman in England published its Axioms of Good Administration, with guidance on the design of complaints procedures. The Parliamentary and Health Services Ombudsman has published similar Principles for Remedy, while the Scottish Public Services Ombudsman has published a Statement on Principles of Good Complaint Handling. The latter document, in particular, shows signs of being influenced by NPM, with principles such as 'user-focused', 'seeking early resolution', and 'deliver improvement' at its heart. In addition to adopting NPM tropes in offering guidance to public bodies, ombudsman offices have themselves been influenced by private sector practices emphasising speedy and cost effective resolution.

Indeed, Seneviratne has described the 'modern purpose' of ombudsman offices as the resolution of complaints, rather than investigation and reporting. ${ }^{57}$ Bondy et al. have charted how informal resolution has become a mainstream approach for UK ombudsman offices, with questions raised about its clarity and fairness. ${ }^{58}$ As Goldsmith has pointed out, informal resolution has been driven by the popularity of Alternative Dispute Resolution and managerial concerns with controlling demand and effective use of resources. ${ }^{59}$ Gill et al. found that ombudsman offices were increasingly devoting more

\footnotetext{
${ }^{54}$ For further discussion see S. Roberts and M. Palmer, Dispute processes: ADR and the primary forms of decision-making (Cambridge: Cambridge University Press, 2005).

${ }^{55}$ M. Adler. 'A socio-legal approach to administrative justice' (2003) 25 Law \& Policy 4.

${ }^{56}$ The idea of 'nesting' and 'nested institutions' refers to the way that 'the behavior of units in any subsystem is inexorably affected by the structure of the system within which the subsystem is nested'. See S. Blavoukos and, and D. Bourantonis, 'Nested Institutions', in R. Biermann and J. Koops (eds.), Palgrave Handbook of InterOrganizational Relations in World Politics (London: Palgrave, 2017), p.304.

${ }^{57}$ M. Seneviratne. Ombudsmen: Public services and administrative justice. (Cambridge: Cambridge University Press, 2002).

${ }^{58} \mathrm{M}$. Doyle, V. Bondy, C. Hirst. The use of informal resolution approaches by ombudsmen in the UK and Ireland: A mapping study (London: Hot off the press, 2014).

${ }^{59} \mathrm{~N} 48$ above.
} 
attention to speedy case disposal. ${ }^{60} \mathrm{~A}$ brief glance at the annual reports of UK ombudsman offices demonstrates that NPM-derived techniques such performance targets, KPIs, and customer satisfaction have been thoroughly incorporated into the practice of ombudsman offices. The emphasis on customerfocused complaint handling can be viewed positively, particularly given concerns about the timeliness of ombudsman offices' investigations. ${ }^{61}$ However, the potential issue is that efficiency rather than fairness becomes the motivating value of ombudsman offices ${ }^{62}$ and that the ombudsman becomes a private adjudicator on transactional matters between consumers and service providers, rather than a key part of the constitutional system for citizens redress. ${ }^{63}$

\section{B. Lesson-learning and the ombudsman: opportunities and risks of the managerial approach}

\section{Learning from complaints and the ombudsman's 'domain perception'}

Gulland has argued that public bodies' complaint handling has emphasised resolving complaints, rather than using them to learn, ${ }^{64}$ despite longstanding calls for them to be used in this way. ${ }^{65}$ Ombudsman offices, on the other hand, have found an opportunity in the NPM reforms' emphasis on using complaints for lesson-learning. As Smith notes in the context of police ombudsman offices, lessonlearning refers to learning from mistakes drawing on principles of organisational learning imported from the private sector. ${ }^{66}$ The opportunity this presents for ombudsman offices is that of escaping the tension that has existed between its two traditional roles: fire-fighting and fire-watching. ${ }^{67}$ Indeed, much of the debate in ombudsman scholarship has been about whether ombudsman offices should focus on providing individual redress or adopt a more systemic function.

This article argues that lesson-learning and the importing of organisational learning perspectives into complaint handling has presented ombudsman offices with the means of redefining their traditionally constrained 'domain' ${ }^{68}$ A 'domain' refers to how organisations present themselves in order to be seen as legitimate by other institutions. As institutions which are nested within both

${ }^{60}$ C. Gill, J. Williams, C. Brennan, N. O’Brien. The future of ombudsman schemes: Drivers for change and strategic responses (Birmingham: Legal Ombudsman, 2013).

${ }^{61} \mathrm{~N} 571$ above.

${ }^{62}$ C. Gill and N. Creutzfeldt, 'The 'ombuds watchers': collective dissent and legal protest amongst users of public services ombuds' (2018) 27 Social and Legal Studies 3.

${ }^{63}$ R. Kirkham, B. Thompson, T. Buck, 'Putting the ombudsman into constitutional context' (2009) 62 Parliamentary Affairs 4.

${ }^{64} \mathrm{~J}$. Gulland, 'Independence in complaints procedures: lessons from community care' (2009) 31 Journal of Social Welfare \& Family Law 1.

${ }^{65}$ For example, J. Allsop and L. Mulcahy, 'Dealing with Clinical Complaints (1996) 4 Quality \& Safety in Healthcare 2.

${ }^{66}$ G. Smith, 'Citizen oversight of independent police services: Bifurcated accountability, regulation creep, and lesson learning' (2009) 3 Regulation \& Governance 4.

${ }^{67}$ C. Harlow and R. Rawlings. Law and Administration (Cambridge: Cambridge University Press, 2009).

${ }^{68}$ S. Gilad, 'Exchange without capture: The UK financial ombudsman service's struggle for accepted domain' (2008) 86 Public Administration 4 
broader public administration and the administrative justice system, ombudsman offices are inevitably influenced by and required to define themselves in relation to wider contextual trends. Lesson-learning is a useful concept for ombudsman offices, because it bridges retrospective accountability and prospective regulation ${ }^{69}$ and allows ombudsman offices to claim that they provide data about consumer preferences of public services, at the same time as feeding back management information for service improvement. ${ }^{70}$ The managerial idea of lesson-learning, therefore, provides ombudsman offices with a language that can be drawn on to manage the tension between individual redress and accountability, and systemic remedy and regulation. As Gilad argues in relation to the Financial Ombudsman Service, ombudsman offices' institutional positions must be carefully delineated in order to achieve legitimacy within regulatory spaces. ${ }^{71}$ Lesson-learning has therefore been a feature of managerialist discourse that has been useful as ombudsman offices increasingly seek to influence, and show their relevance for, public service provision.

This adoption of lesson-learning is not without consequences. One of these is that accountability mechanisms are ill-suited to organisational learning. ${ }^{72}$ Accountability systems focused on blame allocation are often shallow, narrow in focus, and limited in resources, whereas learning requires an examination of systems, actors and processes that can be complex and expensive. A dynamic form of accountability focused on learning, therefore, requires a different methodology and this presents a challenge for ombudsman offices' traditional approach. A key element identified in the literature is a move away from command and control to acting as partners and advisers. ${ }^{73}$ This perspective conforms to the paradigm of responsive regulation, based on trust and cooperation, which dominates modern regulatory practice. ${ }^{74}$ Indeed, attempts to enhance the learning potential of complaints can be seen as attempts to develop quasi-regulatory strategies in the complaint handling sphere. ${ }^{75}$ Writing in the context of health complaints, Beaupert et al. argue that responsive regulation is becoming a hallmark of complaint system governance with traditional adjudication replaced by more strategic regulatory interventions. ${ }^{76}$ Thus, while lesson-learning represents an opportunity for ombudsman offices, it also requires a shift in mind-set and practice.

\footnotetext{
${ }^{69} \mathrm{~N} 66$ above.

${ }^{70}$ C. Hodges, 'Consumer ombudsmen: better regulation and dispute resolution' 15 ERA Forum 4.

${ }^{71} \mathrm{~N} 68$ above.

${ }^{72}$ D. Greiling and A. Halachmi, A, ‘Accountability and organizational learning in the public sector' (2013) 36

Public Performance \& Management Review 3.

${ }^{73}$ Ibid.

${ }^{74}$ R. Bouwman, M. Bomhoff, P. Robben, and R. Friele, 'Patients' perspectives on the role of their complaints in the regulatory process’ (2016) 19 Health Expectations 2.

${ }^{75} \mathrm{~N} 74$ above.

${ }^{76}$ F. Beaupert, T. Carney, M. Chiarella, C. Satchell, M. Walton, B. Bennett, and P, Kelly. 'Regulating healthcare complaints: a literature review’ (2014) 27 International journal of health care quality assurance 6.
} 


\section{The risks of lesson-learning}

The following paragraphs analyse the challenges surrounding learning from complaints. Gill identifies three barriers to the ombudsman's learning role: (i) the complexity of bringing about change in public administration and the empirical evidence suggesting caution in this area; (ii) the contested nature of the ombudsman's role and the potential challenge to its legitimacy; and (iii) limitations in terms of capacity, resources and expertise. ${ }^{77}$ In addition, a number of conceptual and methodological problems face the apparently simple idea of learning from complaints.

Allsop and Mulcahy, for instance, highlight that the relationship between complaints and service failures is complex (some failures do not lead to complaints, some complaints are without foundation). ${ }^{78} \mathrm{~A}$ further challenge is in disentangling learning points from complex personal accounts. Goodman and Newman suggest complaints are unlikely to be representative of broader service failures, ${ }^{79}$ while Christianns-Dinglehoof et al. found that a very small percentage of adverse incidents in a healthcare setting lead to a complaint being submitted. ${ }^{80}$ This issue is acute in relation to elderly, socio-economically excluded, and ethnic minority communities, which are less likely to complain. ${ }^{81}$ The unrepresentativeness of complaint data risks distorting service provision towards the needs of the most vocal.

Despite some case studies showing that learning is potentially powerful, ${ }^{82}$ several studies have reported that complaints are not widely used in this way. ${ }^{83}$ Defensiveness has been a particular concern in the health sector where Bourne et al. have established the significant effects that being subject to a complaint has on doctors' well-being and clinical practice. ${ }^{84}$ These findings are replicated elsewhere and indicate that personal impacts of complaints may limit their value. ${ }^{85}$ Davies and Cleary point to other impediments to using feedback from service users, including: organisational barriers (lack of commitment, competing priorities, and lack of infrastructure), professional barriers (public servants not

\footnotetext{
${ }^{77} \mathrm{~N} 8$ above.

${ }^{78} \mathrm{~N} 65$ above.

79 J. Goodman and S. Newman. 'Understanding customer behaviour and complaints' (2003) 36 Quality Progress 1.

${ }^{80}$ I. Christianns-Dingelhoff, M. Smits, L. Zwaan, S. Lubberding, G. Wal, and C. Wagner 'To what extent are adverse events found in patient records reported by patients and healthcare professionals via complaints, claims and incident reports' (2011) 49 BMC Health Services Research.

${ }^{81}$ E. Grootegoed, C. Bröer, and J. Duyvendak, 'Too ashamed to complain: Cuts to publicly financed care and clients’ waiving of their right to appeal’ (2013) 12 Social Policy and Society 3.

${ }^{82}$ R. Simmons and C. Brennan 'User voice and complaints as drivers of innovation in public services' (2017) 19 Public Management Review 8.

${ }^{83}$ E. Haxby, 'Thinking differently about complaints in the NHS' (2014) 1 Future Hospital Journal 2.

${ }^{84}$ T. Bourne, L. Wynants, M. Peters, C. Van Audenhove, D. Timmerman, B. Van Calster, and M. Jalmbrant, 'The impact of complaints procedures on the welfare, health and clinical practise of 7926 doctors in the UK: a crosssectional survey' (2015) 5 BMJ open 1

${ }^{85}$ For example, J. Bruers, B. van Dam, R. Gorter, and M. Eijkman, 'The impact of a formal complaint on Dutch dentists’ professional practice: a survey study’ (2016) 16 BMC Oral Health 1; C. Gill, C. Hirst, M. Sapouna, J. Williams, The effects of complaints on public service employees (Glasgow: University of Glasgow Project Report, 2017).
} 
being trained to deal with complaints), and expertise barriers (lack of expertise in collecting data and interpreting data). ${ }^{86}$

If learning is to move beyond case studies, complaint systems must make more systematic use of aggregate data. ${ }^{87}$ This requires standardised data, however, standardised approaches to recording, categorising, and analysing complaints are lacking. ${ }^{88}$ According to Gillespie and Reader, the absence of an established taxonomy for collecting data is a critical limitation on learning from complaints. ${ }^{89}$ While some taxonomies have been proposed they have yet to be widely deployed. ${ }^{90}$ Even with systematically designed complaint taxonomies, problems remain around measurement validity, categorisation, and capturing qualitative issues.

In summary, while lesson-learning allows the ombudsman to fit in with NPM paradigms and assist the institution's search for a relevant modern 'domain', it also entails risk: complaint investigation is a relatively straightforward activity; improving public administration through lesson-learning is more complex.

\section{Managerial methodologies: performance management and benchmarking in public services}

The case study in Part III shows the Scottish Public Services Ombudsman using novel methodologies such as performance management and benchmarking to achieve improved complaint handling and lesson-learning. This section provides an overview of these management techniques.

\section{Performance management}

NPM reforms sought to disaggregate policymaking and delivery, open up public services to private providers, and shift public bodies from provision to commissioning. ${ }^{91}$ In this context, performance management becomes increasingly important as increased delegation requires more data for control and accountability. ${ }^{92}$ Springing up alongside this complex landscape of service provision were a host of

\footnotetext{
${ }^{86}$ E. Davies, and P. Cleary, 'Hearing the patient's voice? Factors affecting the use of patient survey data in quality improvement' (2005) 14 Quality and safety in health care 6.

${ }^{87}$ M. Bismark and D. Studdert, D. 'Realising the research power of complaints data' (2010) 123 The New Zealand Medical Journal 1314.

${ }^{88}$ A. Gillespie and T. Reader, 'The Healthcare Complaints Analysis Tool: development and reliability testing of a method for service monitoring and organisational learning' (2010) 25 BMJ Quality and Safety.

${ }^{89}$ Ibid.

${ }^{90}$ J. Fredericks-Younger, M. Handelman-Yellin, J. York, 'Developing a Relevant Taxonomy to Assess Dental School Clinic Patient Complaints' (2017) 81 Journal of Dental Education 3.

${ }^{91}$ C. Hood and R. Dixon, R 'What we have to show for 30 years of new public management: Higher costs, more complaints' (2015) 28 Governance 3.

${ }^{92} \mathrm{H}$. Döring, J.Downe and S. Martin, 'Regulating public services: how public managers respond to external performance assessment' (2015) 75 Public Administration Review 6; C. Hood, 'Public service management by numbers: Why does it vary? Where has it come from? What are the gaps and the puzzles?' (2007) 27 Public Money and Management 2.
} 
bodies to regulate 'within government' ${ }^{93}$ Systems for overseeing public services, therefore, came to rely on 'management by numbers' ${ }^{94}$ This involves setting performance indicators that can take a number of forms, such as intelligence systems, target systems, and ranking systems, and monitoring reported performance against indicators. ${ }^{95}$ Askim et al. define performance management as the measurement, analysis, and communication of performance information with the goal of improvement. ${ }^{96}$

The effectiveness of performance regimes has been widely questioned as a result of unintended consequences and 'gaming' by bureaucrats, ${ }^{97}$ and Cuganesan et al. point out that performance management is a controversial activity that entails significant risks for performance. ${ }^{98}$ Well known problems include ratchet effects (the tendency for targets to be inflated where they have been met), threshold effects (the tendency for performance to cluster around minimal performance), and output distortion (gaming approaches). ${ }^{99}$ The apparently straightforward notion of setting standards and reporting against them, therefore, is in fact underpinned by controversy over what can be measured, measurement errors, and dysfunctional effects. ${ }^{100}$

\section{Benchmarking}

Benchmarking is the process of measuring performance and comparing it against industry leaders. ${ }^{101}$ Benchmarking was developed in the private sector, but has increasingly been used in public services. ${ }^{102}$ In local government, benchmarking has been seen as a means of fostering a private sector mentality and an example of NPM approaches to governance. ${ }^{103}$ In theory, the absence of competition should make benchmarking in the public sector attractive. ${ }^{104}$ However, the concept of 'performance' is more complex

\footnotetext{
${ }^{93}$ C. Hood, O. James, C. Scott, G. Jones, and T. Travers. Regulation inside government: Waste watchers, quality police, and sleaze-busters. (Oxford: Oxford University Press, 1999).

${ }^{94} \mathrm{~N} 92$ above.

${ }^{95}$ G. Bevan and C. Hood, 'What's measured is what matters: targets and gaming in the English public health care system’ (2007) 84 Public Administration 3.

${ }^{96}$ J. Askim, J., A. Johnsen, and K. Christophersen, 'Factors behind organizational learning from benchmarking: Experiences from Norwegian municipal benchmarking networks' (2007) 18 Journal of Public Administration Research and Theory 2.

${ }^{97}$ E. Charbonneau, D. Bromberg, and A. Henderson, 'Steering a Swarm Compliance and Learning in a Municipal Performance Regime' (2016) Administration \& Society (online first).

${ }^{98}$ S Cuganesan, J. Guthrie, and V. Vranic, 'The riskiness of public sector performance measurement: a review and research agenda' (20140 30 Financial Accountability \& Management 3.

${ }^{99} \mathrm{~N} 95$ above.

${ }^{100} \mathrm{~N} 93$ above.

${ }^{101}$ B. Andersen, B. Henriksen, and I. Spjelkavik, 'Benchmarking applications in the public sector principal-agent relationships’ (2008) 15 Benchmarking: An International Journal 6.

${ }^{102}$ D. Ammons, and D. Roenigk, 'Benchmarking and interorganizational learning in local government' (2014) 25 Journal of Public Administration Research and Theory 1.

${ }^{103}$ N 101 above.

${ }^{104}$ N 102 above.
} 
and difficult to measure in public services, so that the reception of benchmarking initiatives has not always been positive. ${ }^{105}$

Scholars distinguish between compulsory and voluntary benchmarking depending on whether participants have chosen to take part. ${ }^{106}$ In addition to variations in the degree of 'vertical' management of benchmarking schemes, distinctions have been made about benchmarking processes. Ammons and Roenigk identify two types: comparison of statistics (where statistics are simply compared and performance gaps identified) and best practice benchmarking (where comparison of statistics is the beginning of a process of analysis). ${ }^{107}$ Ammons and Roenigk argue that best practice approaches are rarely used in the public sector. ${ }^{108}$ As with performance management more broadly, a wide range of challenges face benchmarking schemes including data issues (measurement and comparison) and resource issues (the cost associated with best practice approaches).

\section{Effectiveness and bureaucratic responses}

Do the above strategies enhance performance? Many answers to this question are negative. ${ }^{109}$ Indeed, while collecting data is a ubiquitous activity, using it for improvement is not, ${ }^{110}$ and performance management regimes rarely lead to improved performance or more accountable government. ${ }^{111}$ At the same time, there are clear indications about ways in which performance management and benchmarking initiatives can be designed to minimise risk and enhance effectiveness. Hood, for example, argues that intelligence systems (rather than targets or rankings) reduce incentives for gaming and are more likely to be effective. ${ }^{112}$

Bevan and Hood note that many performance measures are more useful as 'tin openers' than 'dials' (i.e. they provide a prompt for investigation rather than an end point). ${ }^{113}$ This is reflected in the notion of best practice benchmarking in which statistics are only the starting point for analysis and comparison and effectiveness is assessed holistically. Networks and 'learning forums' are important in this context to allow data to be converted into action-oriented responses. ${ }^{114}$ In common with literature

\footnotetext{
${ }^{105}$ W. Rivenbark, D. Roenigk, R. Fasiello, 'Twenty years of benchmarking in North Carolina: lessons learned from comparison of performance statistics’ (2017) 41 Public Administration Quarterly 1.

${ }^{106}$ R. Kitchin, T. Lauriault, and G. McArdl, 'Knowing and governing cities through urban indicators, city benchmarking and real-time dashboards’ (2015) 2 Regional Studies, Regional Science 1.

${ }^{107}$ N102 above.

108 Ibid.

${ }^{109}$ N 92 above and D. Ammons and W. Rivenbark, 'Factors influencing the use of performance data to improve municipal services: Evidence from the North Carolina benchmarking project’ (2008) 68 Public Administration Review 2.

110 Ibid.

${ }^{111} \mathrm{~N} 102$ above.

112 N 92 above.

${ }^{113} \mathrm{~N} 95$ above.

114 D. Moynihan and N. Landuyt, 'How do public organizations learn? Bridging cultural and structural perspectives’ (2009) 69 Public Administration Review 6.
} 
on regulation, performance management and benchmarking scholarship tends to suggest that more collaborative systems are more effective. ${ }^{115}$ The literature also includes a number of typologies to describe bureaucratic responses to performance management regimes (e.g. Bevan and Hood's 'saints, honest triers, reactive gamers, or rational maniacs'), which call attention to the variegated bureaucratic responses that require to be managed in performance management systems. ${ }^{116}$

\section{CASE STUDY}

This part of the article presents a small-scale case study of the Scottish Public Services Ombudsman's (SPSO's) expanded role and its implementation in the local government sector. The purpose of the case study is to provide an illustration of the article's arguments with regard to the influence of managerialism on UK ombudsman practice and an empirical springboard for defining and refining the growth of the 'managerial ombudsman'.

\section{A. Methodology and limitations}

19 interviews were conducted. This included: 3 SPSO staff; 3 senior local government officials; 10 members of the Local Government Complaints Network; 2 staff of Audit Scotland; and 1 advocacy service representative. Individuals were selected using purposive sampling, on the basis that they were able to provide relevant data. ${ }^{117}$ Interviews were conducted in 2017, mostly face-to-face and some by telephone. The average interview length was 55 minutes. Interviews were transcribed and subjected to thematic analysis. ${ }^{118}$ Interviews were supplemented by documentary analysis. Annual complaint reports were collected from local authorities, along with legal and policy texts and SPSO publications such as guidance, annual reports, and online resources.

The methodology had some limitations. A more detailed case study could have been developed by interviewing a wider range of local government staff. Similarly, the views of complainants and other key stakeholders were not collected. Importantly, the case study does not provide an exhaustive empirical account of the SPSO's developing approach and instead is exploratory in nature and aimed at allowing for the development and refinement of broader theoretical conceptions of the ombudsman's role in the modern state.

\footnotetext{
115 N 102 above.

${ }^{116}$ N 95 above.

${ }^{117}$ D. Bryman, Social Research Methods, (Oxford: OUP, 2015).

${ }^{118}$ M. Miles, M. Huberman, and J. Saldana. Qualitative data analysis. (London: Sage, 2013)
} 


\section{B. Case study findings}

The case study is in four sub-sections. The first considers developments in the SPSO's role and the agendas driving reform. The second examines how the SPSO's new responsibilities have redefined its 'domain perception'. The third analyses new methodologies developed by the SPSO. The fourth considers local government responses to the SPSO’s new role.

\section{The SPSO's developing role: consumer-focus and learning}

The SPSO was created by the Scottish Public Services Ombudsman Act 2002. The SPSO was set-up as a 'one-stop-shop' for complaints about all public bodies falling within devolved competence. In effect, it merged four jurisdictions: central government, health, local government, and housing. At the heart of the one-stop-shop were ideas of consumer focus and simplification, and this development can be seen as part of the systemic-managerial phase described in Part II. The one-stop-shop has grown in scope over time with new jurisdictions incorporated: higher education (2005); water and prisons (2010); Scottish welfare fund (2015); and social work (2016).

Attention turned to internal complaint handling when the Scottish Government commissioned the Crerar Review. ${ }^{119}$ Crerar proposed that the ombudsman's role should be to oversee a standardised public service complaint system; effectively, a regulator of internal complaint handling. Crerar was highly critical of existing arrangements for complaint handling, finding them not fit-for-purpose. He recommended that, in designing a new system, the SPSO should be guided by: simplicity, consistency, timeliness, and local resolution. The goals of Crerar's proposed reforms reflect the managerial aspirations of previous Charterist reforms (a) to make it easier for people to get redress and (b) for public bodies to learn from complaints. Indeed, Crerar explicitly stated that his proposals build on previous customer-focused initiatives, such as Customer First.

The consumerist and managerial emphasis of policy continued with the Scottish Government's Fit-For-Purpose Complaints System Action Group, chaired by Douglas Sinclair. ${ }^{120}$ The Sinclair Report developed proposals in relation to the oversight and simplification of complaint procedures. The Sinclair Report recommended basing reforms on two principles: simplification and consumer focus. It continued to emphasise a systemic-managerialist perspective by taking a 'whole system view', and arguing that the arrangements for complaints should be based on the SPSO's existing approach that 'have the consumer at the centre'. Most of Sinclair's recommendations were implemented in the Public Services Reform (Scotland) Act 2010 (see Box 1).

${ }^{119}$ N 33 above.

${ }^{120}$ D. Sinclair, Fit for Purpose Complaint System Action Group Report, (Edinburgh: Scottish Government, 2008). 
New duties to:

- publish a statement of complaint handling principles;

- monitor practice and identify trends in how public bodies handle complaints;

- promote best practice in complaint handling; and

- encourage cooperation and sharing of best practice amongst public bodies.

New powers to:

- publish model complaint handling procedures for public bodies; and

- issue a declaration of non-compliance where a complaints procedure does not conform to a model complaint handling procedure.

Box 1: key provisions of s. 119 of the Public Services Reform (Scotland) Act 2010

The SPSO's strategic plan shows how the SPSO describes its priorities following its expanded functions. ${ }^{121}$ It emphasises consumer focus and learning as the heart of the SPSO’s mission. The plan contains 6 objectives. Objectives 1 and 2 refer to the conduct of 'user-focussed' investigations, with objective 1 referring to providing 'individual benefit to our customers'. Objectives 3, 4, and 6 meanwhile refer to improving public services: objective 3 in relation to complaint systems, objective 4 in relation to better complaint handling, and objective 6 in relation to improving substantive public services. Finally, objective 5 refers to accountability and providing a 'best value' service that is operationally efficient. The language used in the plan draws on consumerist and managerialist language, through its emphasis on 'users', ‘customers', ‘best value', 'learning', and 'improvement'.

\section{The SPSO's domain perception: investigator, regulator, or improvement partner?}

The provisions of the 2010 Act have required the SPSO to reflect on how it situates its role within public administration. SPSO interviewees believed these provisions radically developed understandings of the ombudsman's role:

${ }^{121}$ SPSO, Strategic Plan 2016-2020 (Edinburgh: SPSO, 2016). 
'I used to sit and get lectured about... what we do in Scotland was not what an ombudsman does. And I said, no... You're doing what an ombudsman did. We're doing what an ombudsman does... You're behind us now.' (O1) $)^{122}$

That the new role is perceived as ground-breaking is reflected in the SPSO's ambition to be 'recognised and consulted as a world-leading ombudsman service'. ${ }^{123}$ As we shall see, however, what exactly the role involves and how it is perceived have been matters which the SPSO has had to delineate carefully.

The SPSO implemented the 2010 Act by creating the Complaints Standards Authority (CSA), an internal team operating within the SPSO. The choice of name is intriguing, in that it suggests a regulatory function (c.f. other regulators such as the Advertising Standards Authority). However, SPSO interviewees said they did not consider the CSA to be involved in regulation. Instead, they distinguished CSA activities from other forms of oversight: 'We're not audit, we're not regulation, we're not inspection' (O2). Instead, interviewee $\mathrm{O} 1$ argued that the role was to 'monitor':

'A regulator... is someone who applies a set of rules with penalties. A monitor is someone who sees what's happening and alerts people... The fact that [the Scottish Parliament] asked for that function to be part of the ombudsman's role... helped me to redefine what the ombudsman does.' (O1)

The SPSO, therefore, had to 'redefine' its role, as it incorporated new functions within its existing remit as complaint investigator. In doing so, the SPSO's approach involved creative ambiguity, hinting at a regulatory role, while also distancing itself from it. It seems likely that this caution and ambiguity can be explained by the SPSO's desire to maintain a legitimate domain of operation in relation to other institutional stakeholders, such as public bodies, auditors, and regulators.

An important way in which the SPSO has managed to recast its domain is through emphasising its ultimate goal as public service improvement through partnership and collaboration. Supporting learning rather than adopting a coercive regulatory approach is how 'what the ombudsman does' (O1) is redefined:

'We certainly do have a role in encouraging, facilitating... sharing good practice, and driving up the standards of complaints handling.' (O2)

\footnotetext{
${ }^{122}$ Interviewees are cited anonymously: ombuds staff as O1, O2, etc., local government staff as LA1, LA2, etc., and stakeholders are referred to as $\mathrm{S} 1, \mathrm{~S} 2$, etc.

${ }^{123}$ SPSO, Strategic Plan 2018-2020 (Edinburgh: SPSO, 2018).
} 
The SPSO's new domain, therefore, is re-imagined as involving cooperative forms of oversight described as 'monitoring' and 'partnership'. This was commented on by interviewee O1 who described the way in which the 2010 Act had been implemented:

'If I had... said '[The Scottish] [P]arliament's given me this power', I might have been able to force something through. [However] I think the relationship between the ombudsman and the public bodies would have been damaged... you can't really move from there to partnership.' (O1)

The key partnerships developed in the implementation process were (a) with other oversight bodies, who are expected to monitor performance and (b) with public bodies whose complaint handling performance is being overseen. Local authority interviewees largely agreed that the SPSO's approach was collaborative:

'We've now got a... closer relationship... we're involved... more proactively with the ombudsman in trying to drive up standards... [It is] a genuine partnership' (LA1).

At the same time, the creative ambiguity noted above was picked up by stakeholders. For example, the Society of Local Authority Chief Executives (SOLACE) responded to the SPSO's consultation on its strategic plan as follows:

'[The strategic plan] suffers from a confusion of approaches as to SPSO's mission. Is it:-

- a regulator?

- [a] part of an integrated public sector, focussed on improving outcomes for the community?

- [an] independent body who impartially determines complaints in a quasi-judicial manner? ? $^{124}$

In SOLACE's view, the ombudsman should focus on the second bullet point, with the ombudsman working 'in partnership with the public sector to ensure that its work is targeted towards achieving real and tangible outcomes'. ${ }^{125}$ This perspective, therefore, seeks to shift the SPSO further towards a managerial approach, where the role is one of supporting improvement in public services. Arguably, this is indeed where the SPSO has been focusing its efforts, but there remains a tension as a result of

${ }^{124}$ SOLACE, Consultation Responses on SPSO Draft Strategic Plan 20156-2020 (Edinburgh: SOLACE, 2016). ${ }^{125}$ Ibid. 
the SPSO's variegated remit - which it now defines as 'oversight' and 'development' - and the concurrent need to maintain impartiality, act as an authoritative monitor, and work in partnership. ${ }^{126}$

\section{New methodologies: standards, performance management, and collaboration}

The SPSO's expanded role has required it to develop new methodologies, heavily influenced by managerial practices, including (a) the design of complaint procedures, standards, and performance indicators (b) the use of benchmarking to identify best practice and raise standards, and (c) the use of professional networks and other collaborative tools of governance.

The major initial task for the CSA was to develop Model Complaint Handling Procedures (CHPs). The CHPs involve two stages. Stage 1 is 'frontline resolution' and Stage 2 is 'investigation'. Stage 1 complaints should be resolved within 5 working days, while Stage 2 complaints should be resolved within 20 working days. If a complainant remains unhappy after receiving a Stage 2 response, they may complain to the SPSO. Additionally, CHPs contain guidance about responsibilities within the complaint process, supporting customers, and recording, reporting, and learning from complaints. The CHPs amount to a detailed set of standards for public bodies.

Not surprisingly, given the policy process leading up to the 2010 Act, consumerist and managerialist matters featured heavily in SPSO interviewees' perceptions of the benefits of the CHPs, including: cost reductions; quicker, simpler, and more consistent user experience; and better quality complaint handling outputs. SPSO interviewees also noted that the CHPs had begun to prompt culture change in valuing of complaints: 'I don't think it's there yet, but it's getting there.' (O2). Local authority interviewees also identified a feature of the CHPs being about improving consumer experience: 'It's clear. It's transparent; and the key thing for the complainant is that it's simple.' (LA7). Improving the timeliness of responses through frontline resolution was seen as enhancing efficiency and customer satisfaction: 'There's a known link between kind of speed of resolution and satisfaction.' (LA5). Local authority interviewees highlighted a number of managerial benefits of simplified procedures: it was easier to manage complainants' expectations (LA9); complaint procedures between departments had been harmonised (LA8); the use of Customer Record Management systems had been facilitated (LA8); and a stronger emphasis had been put on performance management (LA2). Local authority interviewees also agreed that the CHPs had begun to allow better learning from complaints:

'We've started down the path of changing the culture... [from] 'complaints are a nuisance' to 'actually they're useful'... Now it has... a place in the organisation.' (LA4)

${ }^{126} \mathrm{~N} 123$ above. 
The SPSO can therefore be seen to have focused on creating a rational, simple, consistent, consumerfocused, and efficient process, where complaints can be more easily recorded, monitored, and reported as a source of management information.

Once the CHPs were introduced, the SPSO developed performance indicators to monitor how they were working. These were designed in partnership and subject to a 'huge amount of to'ing and fro'ing' (LA3). There are 8 performance indicators (PIs) as shown in Box 2.

1. Number of complaints /1000 population

2. Number of complaints closed at stages 1 and 2

3. Number of complaints upheld/ partially upheld/ not upheld at each stage

4. Average response time in working days at each stage

5. Number and percentage of complaints closed within the timescales

6. Number and percentage of complaints where an extension has been authorised

7. Statement to report customer satisfaction with the complaints service

8. Statement outlining improvements to services as a result of complaints

Box 2: The SPSO's performance indicators

The PIs measure (a) the quantity of complaints and the stage at which they are closed (PI1 and PI2) (b) the outcomes of complaint procedures (PI3) (c) the timeliness of complaint procedures (PI4, PI5, PI6) and (d) customer satisfaction (PI7) and learning (PI8). Only PIs 4 and 5 can be considered to be targets, since there are clear timescales in which complaints should be resolved. The other PIs conform to the performance measures used in 'intelligence systems' and are 'tin openers' that allow for comparison between local authorities and self-reflection. ${ }^{127}$

The decision not to use targets as PIs was part of a deliberate strategy to create a bottom-up approach to monitoring and improvement. Indeed, the focus of the PIs is primarily for use as management information by local authorities. The SPSO's guidance states:

'Local authorities are required to assess complaint handling performance to provide assurance in relation to their performance, to facilitate continuous improvement and to assist in benchmarking performance between local authorities, ${ }^{, 128}$.

${ }^{127} \mathrm{~N} 100$ above.

${ }^{128}$ SPSO, Performance Indicators guidance (Edinburgh: SPSO, 2015). 
Interviewees also made clear that external oversight was expected to play a relatively limited role, with the emphasis on 'self-governing' (LA4).

The SPSO used two techniques to realise this: the creation of complaint handling networks and the use of collaborative benchmarking. The networks were seen by the SPSO as key vehicles for implementing the new arrangements:

'[We decided] to concentrate most of our efforts [on]... the people who actually make things work in the complaints world, which was the beginning of the creation of the networks of complaint handlers. And we engaged with people there.' (O1)

The creation of the complaint network was seen by interviewees as a successful aspect of the new system. Interviewees stressed that the network offered an opportunity to review performance in a nonthreatening way that supported improvement:

'We're not banks. We're not competing with each other. We are trying to identify common ground and share best practices.' (LA7)

Although performance data was published, the fact that deliberation took place in private was an advantage, as this removed the pressure that would exist if complaint data became a matter of public debate:

'It's been very much about using it as an internal resource... everyone's committed to improving so there's no naming and shaming...' (LA2)

This non-coercive approach is also evidenced by the fact the SPSO has yet to declare a local authority non-compliant.

The role ambiguity identified above meant that, although most interviewees saw the SPSO's approach as one of partnership, a tension was identified between working collaboratively and authoritatively:

'... it comes back to this idea of a tension... between the SPSO wanting... the local authorities to go over to the two stage process, and being reasonably prescriptive about it, but also saying, look you do this however works best for your organisation...' (LA3)

LA6 felt that the SPSO was overly directive in its approach and had not adopted the kind of partnership approach recommended by SOLACE: 
'I wish there was just more of that kind of... 'we're all working as one bigger organisation to improve customer experiences' rather than 'here's a new process, you have to follow it.' (LA6)

Others noted that while local authorities were supposed to be 'self-governing' some fundamentals had been imposed:

'We're kind of left to do self-governing as well as benchmarking and improvement, and I think it's very difficult when you disagree on the fundamentals...' (LA4)

This mixed approach, combining authoritative standards with engagement and the fostering of cooperation was also noted by SPSO interviewees: 'We took quite a bit of time taking people with us, but very firmly saying, you know, there are red lines here.' (O1)

\section{Bureaucratic responses and organisational learning}

The data presented above shows that the response of local authorities to the SPSO's new role has been largely positive. However, there was a view that resistance to complaints remained within local authorities:

'... if you have a cultural [approach], 'I don't want a complaint', 'that's not a complaint'... then it's extremely difficult... people see a complaint as a hand grenade with the pin taken out.' (LA7)

A large part of the resistance that complaints engendered was that they were taken personally, rather than as learning opportunities:

'You're asking people to admit that a mistake was made and they could do things better. So it does require... that the organisation actually does want them to [learn].' (LA9)

Interviewee LA6 noted that the 'human challenge' of getting people to feel differently about complaints remained, even if technical challenges could be resolved: 'The other challenge is people just not taking the data personally... That's a human challenge rather than a data challenge.' (LA6) Therefore, while the complaint specialists who formed the bulk of our sample were positive about complaints, views in local government more broadly were likely to be mixed.

Interviewees discussed the human challenge of shifting perceptions of complaints as accompanied by the technical challenge of learning from complaint data. Basic compliance with the CHPs was unproblematic with the real question described as the 'so what?' (LA1): 
'What's important in all this stuff we're doing, the capturing and recording... has got to be, how does it improve services for Joe Bloggs, for the customer... The numbers are all very well, but what's changed?' (O2)

Learning from complaints was - despite being the ultimate goal of the SPSO's reforms - a challenge, which all interviewees struggled with. Indeed, most interviewees identified problems with interpreting complaint data and understanding how data could be used to improve: 'When you look at the quantitative side of things, people will say, well so what, what's that actually telling us?' (LA1); 'It's quite difficult for us to spot a trend at the minute' (S3). Although 'the theory is good' (LA2), interviewees noted that it had been difficult to use complaint data for improvement:

'There was an idea when we first started analysing this that there would be patterns ... [but] the complaints vary so much it's quite hard to see patterns and connections.' (LA2)

Low volumes of complaints in some areas exacerbated the issue, as authorities were left with a 'real variety of issues' (LA4). The same interviewee noted that the SPSO's expectations of learning from complaints was 'really quite aspirational' (LA4), while several noted that more resources were required to implement improvements:

'You might identify an improvement... it might be screaming out at you... [but] there's no funding or resource or budget for it.' (LA7)

A further challenge related to the nature of what could be learned from complaints. For example, a number of interviewees reported that learning was impeded because of the sensitivity and specificity of issues:

'The whole learning from complaints issue... everybody's quite obsessed by it... but it's difficult sometimes to do... a lot of them are just more a unique set of circumstances... it's about confidentiality as well and people not being identified.' (LA 10).

The tension between collecting qualitative and quantitative data was also important. While having sufficient data was necessary to persuade people that issues required to be addressed, interviewees tended to agree that qualitative information was more useful: 'That isn't something you can just reduce to a numerical indicator really.' (LA2); 'Numbers are boring for people... They need to understand more what's behind the numbers' (LA6). A further question raised by some interviewees related to capacity in making the best use of data: 
'I don't see much evidence of people managing by numbers... It's just getting people to actually give a monkeys about the information.' (LA5)

Indeed, challenges around recording and using data frequently surfaced in local authority interviews, with a lack of confidence in data recording consistency between local authorities, which hampered benchmarking. A much-mentioned issue was the distinction between a complaint and a request for a service:

'Somebody would phone up to say, the bin lorry has gone past, you've not picked up my bin. Is that a complaint...?... When does a service request become a complaint?' (LA9)

This issue meant that some interviewees expressed scepticism about the extent to which comparison of complaints data could lead to improvements. This was compounded by differences between local authorities:

'We've got different sizes of population, we've got different sizes of organisation, we've got different structures... There are intricacies that the performance indicators we've got don't necessarily weigh up.’ (LA1)

Despite identifying learning from complaints as a challenge, interviewees nevertheless described changes in the way complaints data were reported and used within local authorities. Indeed, interviewees described extensive internal reporting arrangements:

'Our complaint data is... done quarterly and reported annually... Then there are the internal reports that... go to our senior management team, our heads of service, our service managers.' (LA10)

Some interviewees also emphasised that complaints were useful for managers, for example, providing opportunities for scrutiny:

'There's usually a good debate at the committee when it comes up. There are always questions and we usually end up having to go away and do a bit more digging.' (LA2)

Indeed, most interviewees were also able to cite at least one example of complaint data being used for learning in their authorities. Interviewees also noted that attempts to use data to drive learning had to be put in context: 
'What I'll place on record here is a recognition of where we are, compared to where we were... This inconsistent, broken, not fit-for-purpose system, where complaints data wasn't captured, wasn't used. We are in a far, far better position now.' (O2)

'Historically a report never went to the corporate management team... The in-depth discussions that go on around complaints, the sharing of information that goes on, it was never there.' (LA8)

SPSO interviewees also noted that learning from complaints remained a work in progress. For example, the SPSO has recently created a Learning and Improvement Unit (LIU). This is described in the SPSO's Strategic Plan as supporting 'authorities to take action to learn from complaints effectively and to implement improvements that prevent repeat service failings and address any systemic issues identified by our decisions ${ }^{129}$ The LIU is a further development of the SPSO's work on learning from complaints, involving a consultancy style advice and support service.

\section{DISCUSSION AND CONCLUSIONS}

\section{A. Case study analysis and discussion}

This section analyses the SPSO's new role and argues that it represents a significant extension of managerial approaches in ombudsman practice. ${ }^{130}$ This can be seen in the policy process leading to the 2010 Act, which was driven by agendas that share a great deal with the original Citizen's Charter reforms of the 1990s and the Service First reforms of the early 2000s. Placing 'the consumer at the heart' of the complaint system ${ }^{131}$ and emphasising learning and managerial improvement, situates reforms in Scotland as inheritors of the consumerist and managerialist ideas that have been hugely influential in shaping complaint handling in the UK. The emphasis on simplification and consistency is also in keeping with the $21^{\text {st }}$ century emphasis on a systemic-managerial model, where the focus is how complaints procedures - as a whole - function as a system.

On the one hand, therefore, the SPSO's new role can be seen as continuing broader trends. However, this should not obscure the fact that its expanded role and the techniques deployed to implement it, represent significant extensions to the traditional ombudsman approaches. That this role remains somewhat ambiguous came out clearly in the interview data. The balance needed between

\footnotetext{
${ }^{129} \mathrm{~N} 123$ above.

130 A normative critique of these developments and how they can be reconciled (or not) within different constitutional conceptions of the ombuds' role has previously been provided in Gill (2014), and as a result these matters are not considered in detail here.

${ }^{131} \mathrm{~N} 123$ above.
} 
impartiality, setting standards, and working in partnership arose both in how the SPSO has redefined its role and how it has implemented its new remit. While, in practice, the SPSO keeps an internal separation between caseworkers and the Complaints Standards Authority staff, at an institutional level these functions exist in some tension with each other. Seeking to fulfil a more multifaceted role has presented the SPSO with a need to carefully mark out a place in relation to its key stakeholders. Gilad has written about the difficulty experienced by the Financial Ombudsman Service in delineating a legitimate 'domain' of operation between courts on the one hand and regulators on the other. ${ }^{132}$ While the regulatory context is different for public services, the concept of domain perception is useful for describing the way in which the SPSO has sought to present and develop its new functions. This at once hints at formal authority, while mostly stressing collaborative strategies.

Indeed, in addition to requiring the SPSO to distinguish their role from that of others, new challenges have emerged in relation to the methodology the ombudsman's office should employ. Here, the SPSO's strategy can be seen to conform to principles of reflexive regulation ${ }^{133}$ and ideas about collaborative governance. ${ }^{134}$ Both in its oversight and its more developmental guises, the SPSO has emphasised a collaborative approach, using consultation, co-creation, and peer-review techniques in preference to more directive oversight. This is in keeping with much of the literature on the effectiveness of performance management and benchmarking techniques in government. ${ }^{135}$ At the same time, interviewees noted some tension between the need for authoritative 'red lines' (O1) and a desire to work in 'genuine partnership' (LA 4). This resulted in a hybrid domain perception and a hybrid methodology, involving elements of top-down standard setting and bottom-up service improvement.

It is interesting that in interviewees' accounts the collaborative approach was seen as particularly effective; this accords well with modern theories of regulation, which emphasise coercion as a last resort. ${ }^{136}$ This does of course represent a significant move away from the ombudsman's traditional role as investigator, since the kind of relationship with public bodies required to carry out both regulatory activities based on reflexive principles and developmental work designed around supporting improvements is quite different. No longer is the SPSO merely the arbiter between a citizen and a public body. Instead, the SPSO oversees the quality of complaint handling in public services and the operation and design of public services themselves, through its championing of complaint-driven service improvement. Despite seeking to side-step labels such as regulation, audit, and so on, it is nonetheless clear that the interactions with public service providers required by its new remit represent

\footnotetext{
132 N 6 above.

${ }^{133}$ I. Ayres and J. Braithwaite. Responsive regulation: Transcending the deregulation debate. (Oxford: Oxford University Press, 2005); R. Baldwin and J. Black, 'Really responsive regulation’ (2008) 71 The Modern Law Review 1.

${ }^{134}$ N 72 above.

${ }^{135} \mathrm{~N} 102$ above.

${ }^{136} \mathrm{~N} 76$ above. The approach also fits strongly within a model of regulation that seeks to devolve responsibility to regulatees, with regulators operating a form of 'meta-regulation' involving the oversight of self-regulation, See C. Parker, The Open Corporation (Cambridge: Cambridge University Press, 2002).
} 
a shift in both operational style and mind-set. While this builds on what has previously been identified as the more cooperative 'control style' of ombudsman offices, it nonetheless represents a significant development of it. ${ }^{137}$

Thus, while investigation and reporting and informal resolution previously formed the mainstay of UK ombudsman practice, ${ }^{138}$ the SPSO has devised new reflexive and managerial methodologies. These have centred on the setting of performance indicators and the use of benchmarking. The use of these techniques is fascinating, since it shows the ombudsman not only working in pursuit of longstanding managerialist goals, but - for the first time - also deploying techniques associated with NPM. Indeed, the performance indicators and their predominant emphasis on outcomes, efficiency measures (especially timeliness), consumer satisfaction, and learning fit well with what Clark describes as the 'consumer-variant' of NPM. ${ }^{139}$ Similarly, the use of benchmarking is one of the prime examples of the use of private sector management methodologies in the public sector. It is in this sense - not only in terms of aims and rhetoric, but in terms of tools and techniques - that the case study of the SPSO allows us to identify particularly clearly the continuing growth of managerial approaches in UK ombudsman practice.

While the case study highlights an important development in the ombudsman's role, it should not be over-stated. Despite the Complaints Standards Authority role becoming a more significant aspect of the SPSO's strategy and operations, complaint handling remains at the heart of the ombudsman's activity. Most of the SPSO's staff remain employed in complaint handling roles and it is from this that the organisation derives the credibility to deliver its wider systemic functions. This article is not, therefore, arguing that the SPSO's traditional complaint handling function has been replaced. Rather it argues that the influence of managerialist ideas has spread from how the SPSO has conceptualised its casework (KPIs, an emphasis on informal resolution, etc.) to how it engages with bodies under its jurisdiction and sees its role in influencing and improving public services. In that sense, the case study shows a new phase in the development of managerial practices within the UK ombudsman sector and suggests an acceleration in the use of managerial tools within ombudsman practice.

The case study research was not designed to evaluate the success of the SPSO's new role. Nonetheless, it offers some indications of the opportunities and challenges inherent in it. It seems clear from the case study that the re-design of local government complaints procedures has been successfully implemented and that, among the complaints specialist and senior staff in our sample, there was commitment to improving complaint handling. Although there was some scepticism about how far this extended among colleagues, most interviewees believed that the new complaints system was beginning

\footnotetext{
${ }^{137}$ M. Hertogh, 'Coercion, cooperation, and control: Understanding the policy impact of administrative courts and the ombudsman in the Netherlands' (2001) 23 Law \& Policy 1.

${ }^{138} \mathrm{~N} 57$ above.

${ }^{139} \mathrm{~N} 11$ above.
} 
to engender a culture change. The technical task of simplifying complaint procedures and prompting local authorities to pay attention to complaints data appears to have been achieved with few problems.

At the same time, particularly in focusing on 'learning' as the key underlying purpose of the complaint enterprise, a number of challenges face the ombudsman. Interviewees discussed difficulties in both identifying and reporting on the learning from complaints, as well as more fundamental human and data issues that stood in the way of change. Moving from a classic investigator to a performance manager concerned with organisational learning in the public services, requires both a sanguine view of what is possible and the development of new skills, methodologies, and capacities. The design of performance indicators, the operation of benchmarking groups, and, underlying this, a much stronger emphasis on data science, including the reliable collection, categorisation, and interpretation of data all require a much expanded skill-set. Ombudsman offices have a long experience of drawing out qualitative lessons from investigations, but much less in overseeing the production and use of meaningful quantitative data. Here, there may be lessons to learn from embryonic attempts at making systematic use of health complaints data. ${ }^{140}$

\section{B. The managerial ombudsman: implications in the UK and beyond}

To what extent is the SPSO's approach relevant to ombudsman offices in the UK and elsewhere? Its relevance is most obvious for other UK ombudsman offices, where the SPSO's CSA has been seen as a model to follow. Part 3 of the Public Services Ombudsman Act (Northern Ireland) 2016, for example, makes provisions that replicate the provisions in s. 119 of 2010 Act. ${ }^{141}$ In Wales, similar provisions are included in the Public Services Ombudsman (Wales) Bill. In England, a watered down version of the Scottish arrangements is proposed: clause 27 of the draft Public Services Ombudsman Bill's proposes only to impose a duty on the ombudsman to provide information, advice and training to promote best practice in complaints and for bodies under jurisdiction to take account of this. Assuming these proposals survive the legislative process, the UK's devolved jurisdictions will all adopt the CSA, while England will adopt minor aspects of it (if the Public Services Ombudsman Bill is enacted). Consequently, the SPSO's approach and the way in which it has developed ombudsman practice is of significant interest here.

Looking further afield, while the CSA appears to be unique in ombudsman practice, questions about the proper role of the ombudsman and the need for caution in how the role is developed are not. ${ }^{142}$ On a global scale, the major story of the ombudsman's development has been its flourishing as an institution involved in good governance and protecting human rights. ${ }^{143}$ This emphasis on human rights

\footnotetext{
140 N 88 above.

${ }^{141}$ Part 3 of the 2016 Act has yet to come into force.

${ }^{142}$ A. Stuhmcke, 'Australian Ombudsmen: A Call to Take Care’ (2016) 44 Federal Law Review.

${ }^{143}$ B. Tai, ‘Models of Ombudsman and Human Rights Protection’ (2010) 1 International Journal of Politics and Good Governance 1
} 
protection has clearly not featured evenly in the development of the ombudsman: in the UK, as we have seen, human rights have not been prominent in debates about ombudsman reform. In Australia, the emphasis on developing more systemic ombudsman approaches, incorporating a range of new functions and methodologies such as audit or inspection ${ }^{144}$ can be seen as part of a similar, more managerial approach to the ombudsman's role. In Europe, a recent influence has been the growth in ombudsman offices in the private sector, catalysed by the EU's Directive on Consumer Alternative Dispute Resolution (2013/11/EU). O’Brien has argued that developments in private sector redress have led to an inappropriate focus on providing customer satisfaction amongst public services ombudsman offices. ${ }^{145}$ In his view, this limits the potential of public service ombudsman offices and moves the institution towards a narrow redress model.

The argument, therefore, is that the managerial ombudsman paradigm and the case study analysed in this article are relevant for a number of reasons. First, while the article has focused on the managerial trajectory of reform in the UK, similar reforms of public services have been undertaken in many countries across the world in the last 30 years, with systems for 'voice' forming a key part of increasing the responsiveness of public services to 'consumers'. Second, the debate about the ombudsman's role and its proper limits has been a continuous feature of ombudsman scholarshipespecially with regard to the extent to which more systemic or more narrowly adjudicative approaches should predominate - and a matter of pressing contemporary concern in some jurisdictions, such as Australia. ${ }^{146}$ Third, looking at the issue the other way, the managerial ombudsman - incorporating the aims, languages, and tools of managerialism - provides a strong contrast to models globally that stress the rule of law, anti-corruption, and human rights. ${ }^{147}$

An important question, then, relates to the significance of these developments. O’Brien argues that the normative implications of shifts towards private sector practice and consumerisation present an existential threat to the public sector ombudsman. ${ }^{148}$ Certainly, the lack of prominent debate in the UK around issues such as the rule of law and human rights, casts the ombudsman less as a repository of fundamental values, and more as one of a plethora of bureaucratic actors focused on enhancing managerial performance. While the ombudsman's nested position within public administration means that it is perhaps inevitable that these agendas will influence its practice to a degree, institutional context is not determinative and the ombudsman institution has at least some freedom to carve out its own legitimate 'domain'. ${ }^{149}$ As things stand, however, there are strong indications that the managerial ombudsman approach has co-opted ombudsman offices to agendas whose philosophical underpinnings

\footnotetext{
${ }^{144}$ A. Stuhmcke, 'The evolution of the classical ombudsman: a view from the antipodes' (2012) 2. International Journal of Public Law and Policy 1.

${ }^{145} \mathrm{~N} 38$ above.

${ }^{146} \mathrm{~N} 142$ above.

147 N 9 above.

148 N 38 above.

${ }^{149} \mathrm{~N} 6$ above.
} 
- emphasising private sector practice, recasting citizens as consumers - fundamentally jar with the provision of justice.

In evaluating these issues, there is a need to distinguish between the tools and values of managerialism. Managerial tools such as KPIs, performance management, early resolution, benchmarking, and consultancy have the potential to enhance the ombudsman's practice and to bolster the institution's arsenal of techniques to bring about fairness in administration. In order to keep pace with modern administrative practice, it is simply not viable for the ombudsman to remain limited to investigation and reporting. As noted above, whether this expanded arsenal is effective remains a matter for further empirical enquiry, but broadening the ombudsman's toolkit and providing new avenues for it to influence administration appear to be a desirable adaptation. The real question relates to the values of managerialism. The danger with adopting such values is that the ombudsman loses its ability to maintain an independent critique of public institutions, which are themselves dominated by a managerial ethos. A managerial ombudsman, overseeing a managerial public administration may serve merely as a tool for maintaining the current administrative orthodoxy rather than as a means of challenging it. This can be seen in the case study, with the SPSO's heavy emphasis on efficiency and speed as the guiding values of Scotland's new public service complaint system, which can be seen as realising long-standing consumerist and managerial reforms rather than suggesting an alternative and distinctive vision for bringing about fair administration. There is a need, therefore, to resist further encroachment of managerial values in respect of the ombudsman institution and not to allow the use of modern managerial tools to import values that - if allowed to dominate - will ultimately reduce the effectiveness of the ombudsman as a check on administration.

Instead, the UK ombudsman sector should reflect upon and seek to enunciate a set of values that allows the office's mission to be set aside from that of the broader managerialist project of public administration reform. For example, although the SPSO's CSA approach is grounded in a managerialist and consumerist paradigm, the model could potentially be reconciled with other philosophical approaches to the ombudsman's role. For example, the Northern Ireland Public Services Ombudsman is the only UK ombudsman to adopt an 'explicit' human rights approach ${ }^{150}$ to its casework and its forthcoming adoption of the CSA model will provide a test case for combining the approaches. Certainly, there would be nothing precluding NIPSO from designing principles for complaint handling that focused less on efficiency, customer satisfaction, and management information and more on human rights, democratic participation, and citizenship. Despite its managerialist roots, therefore, the CSA approach may well be capable of adaptation and transplantation. The point is that the new managerial tools developed in the UK and exemplified in the SPSO's current approach could be deployed in other contexts and in order to fulfil different values. Conversely, the UK ombudsman institution could usefully consider international models and the developing model in Northern Ireland in order to escape

${ }^{150} \mathrm{~N} 143$ above. 
being in thrall to managerial values and to resist rather than replicate the dominant logic of modern administration. ${ }^{151}$

\section{Situating the managerial ombudsman: managerialism in the broader justice system}

This article started with reference to Selznick's concept of the 'managerial judge' ${ }^{\text {'52 }}$ and, in this final section, the article argues that the development of the managerial ombudsman should be seen as part of a broader programme of managerial reforms of the justice system. As noted in Part I above, developments in the ombudsman institution can be seen as occurring in broad phases, which mirror wider shifts in public administration. As such, the ombudsman can again be conceived as a nested institution, operating within and constrained by its wider institutional context, and influenced by and reflecting broader patterns of change in public administration and the wider justice system. The connections between managerialism and reforms of the justice system have been most strongly advanced by criminal justice scholars. The dominant theme in this literature is to suggest that managerial practice in the judicial system is problematic and risks undermining the rule of law, although some argue that these concerns are overplayed and that managerial reforms are, in fact, required for the achievement of justice. ${ }^{153}$ There is broad consensus, however, that whatever its merits managerialism is now a core feature of the criminal justice system.

The influence of new public managerialism on civil and administrative justice has also been discussed. ${ }^{154}$ In the civil justice arena in England and Wales, the major concern has been about the way in which the Woolf and Jackson reforms of civil procedure, which emphasise case management, settlement, and the use of Alternative Dispute Resolution (ADR) have led to a privatisation of dispute resolution. ${ }^{155}$ The drive for efficiency, cost-effectiveness and disposal of disputes is argued to undermine the value of public adjudication and to effectively privatise matters that are of public interest.

\footnotetext{
${ }^{151}$ An interesting example is the way in which the French ombudsman - the Médiateur has been re-branded as the Défenseur des Droits (Defender of Rights). This is part of a broader international movement towards the mainstreaming of human rights within the missions of ombudsman institutions. See L. Reif (N 9 above).

${ }^{152} \mathrm{~N} 3$ above.

153. McEwan, 'From adversarialism to managerialism: criminal justice in transition' (2011) 31 Legal Studies 4; S. Baicker-McKee, 'Reconceptualizing Managerial Judges' (2015) 65 Amhurst University Law Review; A. Freiberg, Managerialism in Australian criminal justice: RIP for KPIs (2005) 31 Monash University Law Review; A. Jordanoska, 'Case management in complex fraud trials: actors and strategies in achieving procedural efficiency' (2017) 13 International Journal of Law in Context 3; J. MacFarlane and G. Stratton, 'Marginalisation, managerialism and wrongful conviction in Australia' (2015) 27 Current Issues in Criminal Justice; M. McConville and L. Marsh, 'Adversarialism goes West: Case management in criminal courts' (2015) 19 The International Journal of Evidence \& Proof 3.

${ }^{154}$ G. Drewry, L. Blom-Cooper, C. Blake. 2007. The Court of Appeal. (Oxford: Hart Publishing, 2007).

${ }^{155}$ L. Mulcahy, 'The collective interest in private dispute resolution' (2012) 33 Oxford Journal of Legal Studies 1.
} 
As Genn notes, civil justice reforms aimed to transform judges into managers tasked with the realisation of cheaper and more efficient justice system. ${ }^{156}$

Wolff argues that changes in the judicial role have effectively transformed the judge from passive umpire to an activist figure managing settlement dynamics. ${ }^{157}$ In addition to focusing on judicial case management, several authors have considered the broader managerial structure within which judges work. The introduction of targets, Key Performance Indicators, and other quantitative means of managerial oversight have been hugely influential and in some cases inimical to the substantive goals of justice. ${ }^{158}$ Such concerns arise in a number of jurisdictions, with Holvast and Doornos citing a manifesto produced by Court of Appeal judges in the Netherlands, in which judges complained:

'Increasingly, courts are managed like large companies, in which... the Council for the Judiciary acts as a "Board" and court managers as "Divisional Boards". (...) output norms and budgets have become dominant.... (A)s a consequence, the quality of the administration of justice is under pressure... and irresponsible choices have been made to meet outcome criteria. The judiciary is not a place for production workers.... ${ }^{159}$

Macfarlane and Stratton refer to similar concerns being expressed by the Chief Justice of the Victoria Supreme Court, who argued that performance measures risked turning the justice system into a 'car factory' concerned only with delivering pre-determined outputs. ${ }^{160}$ Again, the encroachment of managerialist practice is seen as being conflict with traditional concepts of justice and future research will need to continue to evaluate how this conflict plays out in practice.

To conclude, the use of managerial language, ideology, and practices can be seen as a common feature of the development of the managerial ombudsman and managerial reforms of the broader justice system. A shared concern with ideas of proportionality, efficiency, informal resolution and settlement, and the use of more proactive strategies in the resolution of disputes clearly animate both the modern approaches of ombudsman offices and other justice system actors. The development of the managerial ombudsman should be seen, therefore, as going with the grain of broader justice system reform; and the case study presented in this article should be understood as an illustration of new, ever more proactive forms of managerialism in the justice system.

\footnotetext{
${ }^{156} \mathrm{H}$. Genn, 'What is civil justice for? Reform, ADR, and access to justice' (2013) 24 Yale Journal of Law and the Humanities 2.

${ }^{157}$ T. Wolff, 'Managerial Judging and Substantive Law' (2012) 90 Washington University Law Review.

158 J. Spigelman, 'The New Public Management and the Courts' (2001) 75 Australian Law Journal.

${ }^{159}$ N. Holvast and N. Doornbos. 'Exit, Voice, and Loyalty within the Judiciary: Judges' Responses to New Managerialism in the Netherlands' (2015) 11 Utrecht Law Review 2.

${ }^{160} \mathrm{~N} 153$ above.
} 